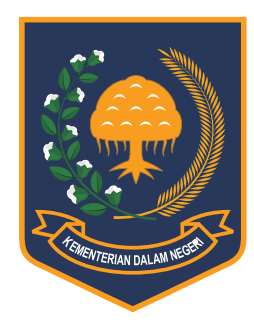

JURNAL BINA PRAJA

e-ISSN: 2503-3360 | p-ISSN: 2085-4323

Accreditation Number

21/E/KPT/2018

http://jurnal.kemendagri.go.id/index.php/jbp/index

\title{
DEFINING INCLUSIVENESS IN DEVELOPMENT: PERSPECTIVE FROM LOCAL GOVERNMENT'S APPARATUS
}

\author{
Ida Widianingsih ${ }^{1}$, Caroline Paskarina ${ }^{2,}{ }^{*}$ \\ ${ }^{1}$ Executive Director of Center for Decentralization \& Participatory Development Research/Associate Professor \\ at Public Administration Department, Faculty of Social and Political Sciences, \\ Universitas Padjadjaran, Indonesia \\ Jl. Bukit Dago Utara 25, Bandung, Indonesia \\ ${ }^{2}$ Senior Researcher at Center for Decentralization \& Participatory Development Research/Associate Professor \\ at Political Sciences Department, Faculty of Social and Political Sciences, Universitas Padjadjaran, Indonesia \\ Jl. Bukit Dago Utara 25, Bandung, Indonesia
}

Received: 19 March 2019; Accepted: 8 July 2019; Published online: 8 November 2019

DOI: $10.21787 /$ jbp.11.2019.137-147

\begin{abstract}
This article discusses how inclusive development is translated into policy and regional development planning. Inclusive development has been a buzz word since the implementation of sustainable development paradigm. Perspectives used are that of the regional government apparatus in-charge of development planning. As a strategic actor in decision making, those in charge of development planning hold an important role in determining what counts as inclusive development, who the targets are, and how such inclusivity could be realized through development programs. The research was conducted in Bandung Regency, one of the regions that have been experiencing rapid economic growth, as well as one that is facing the challenges of poverty and the decline of environmental support capacity. These indicates that there is still a gap between inclusive commitment and practice of resource's allocation through planning and budgeting policy. To reveal the reason behind this gap, this research applies mixed method analysis from survey questionnaire and textual analysis of regional development planning documents. This initial research concludes that policy and practice of development in Bandung Regency has not go beyond a narrow understanding of development as a primarily economic process to an integral focus on the achievement of equity and the rights of citizenship. The issues of poverty and the poor are mentioned in development planning strategic documents. However, the programs create to overcome these issues are still uncomprehensive and sectoral based, aimed only to pursue macro indicators of development. Therefore, there is a need to create a comprehensive effort towards achieving an inclusive development agenda as the primary goal in Bandung Regency development.
\end{abstract}

Keywords: Inclusive Development, Government Apparatus Perception, Development Planning Document Analysis.

\section{INTRODUCTION}

Inclusive development issues evolve along with the rise of critics on development practices that focus solely on macroeconomics indicator achievements (Gupta \& Vegelin, 2016, p. 541; Rauniyar \& Kanbur, 2010, p. 4; van Gent, 2017, p. 7). Despite the fact that development practices in the last half-decade have successfully brought tremendous progress to the increase of human living standards, the issues of poverty, inequality, and environmental degradation have emerged as the result of an exploitative type of development. Such problems have led to the emergence of sustainable development discourse that attempts to balance economic growth and societal cohesion along with environmental preservation (Gupta \& Vegelin, 2016).

Growth can be pro-poor without being inclusive, since (as happened in many countries over the past two decades), growth can be accompanied by falling poverty but rising inequality (Rauniyar \& Kanbur, 2010, p. 3). The concept of development differs from growth in expanding the focus from income alone to other dimensions of well-being, in particular

\footnotetext{
* Corresponding Author

Phone : +62 818219170

Email : caroline.paskarina@unpad.ac.id
} 
education and health. Inclusive development thus refers to the improvement of the distribution of wellbeing along these dimensions at the same time as the average achievement improves. As noted by van Gent $(2017$, p. 7), inclusive development thinking was arguably sparked by the recognition of (I) universal human rights in the 1940s; (ii) investing in countries 'lagging behind' in development in the 1950s and (iii) human rights to protect political, economic and social rights in the 1960s. According to Gupta, Pouw, \& Ros-Tonen (2015, pp. 542-545), this development led to a growing need for a new, more inclusive international economic order.

The Millennium Development Goals (MDGs), a global commitment that was adopted in the year 2000 , are designed to promote welfare equality by focusing on eradicating poverty (Gupta \& Vegelin, 2016). The MDGs agenda have united various stakeholders globally to change the prevailing development paradigm, by prioritizing the eradication of poverty. Despite the fact that the achievements of MDGs may vary, the paradigm shifts on development that it brought have provided the opportunity for the entry of environmental issues in the development agenda. This commitment is marked with the adoption of a global agreement in the year 2015, in the form of the document "Transforming our World: The 2030 Agenda for Sustainable Development", that contains the agenda for Sustainable Development Goals (SDGs) (Gupta \& Vegelin, 2016). This agreement underlines the importance of inclusive development that is hoped to be able to encourage changes towards sustainable development that are based on human rights and equity in order to promote social, economic, and environmental development (van Gent, 2017).

Indonesia's commitment in supporting the SDGs agenda among others are recorded in the Presidential Regulation Number 59 Year 2017 on the implementation of Sustainable Development Goals (Pelaksanaan Pencapaian Tujuan Pembangunan Berkelanjutan, TPB). The regulation aims to ensure Indonesian SDGs achievement through developing national policy framework such as Roadmap to 2030, National Action Plan, and Local Government Action Plan (Rencana Aksi Nasional dan Rencana Aksi Daerah SDGs).

Development policy is a product of political commitment. The government, as strategic actor with authority to determine resources' allocation can be highly capable without necessarily being committed to development. Several researches noticed that the commitment of political elites to delivering development has also proved critical (Booth, 2011; Hossain \& Moore, 2002; Leftwich, 1995; Vu, 2007). State capacity and elite

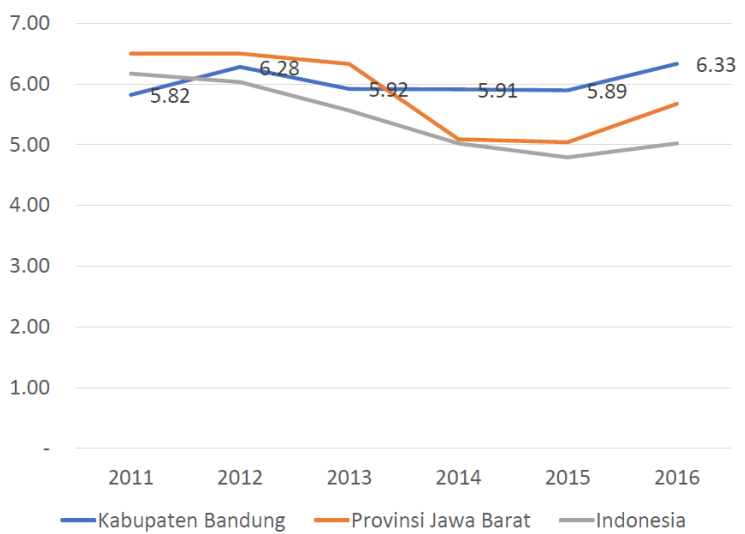

Source: Faculty of Post-Graduate, Universitas Padjadjaran, elaborated from various data sources, 2018

Figure 1. Comparison between the economic growth of Bandung Regency to that of West Java's and Indonesia's

commitment are both critical to securing inclusive development outcomes. High levels of state capacity have been a central feature in all successful (Hickey, 2015). Therefore, to support the realization of that commitment, the relational basis of elite behavior and institutional performance need to be synchronized.

Despite this consensus, there is far less agreement concerning the specific types and levels of commitment that matter for delivering different forms of development. Nor do we have a clear understanding of the particular conditions under which these forms of commitment emerge and can be sustained.

This article will discuss how the regional government translates inclusiveness into development practices as part of government's commitment to inclusive development. Several researchers found that government institutions hold an important role in the realization of inclusive development (OECD, 2016; Shankar Aiyar, 2015), especially due to the fact that the government has the authority to formulate policies as the basis in the practices of inclusive development. Policies become strategic instruments in order to ensure that economic growth are distributed equally for the entire society. These policies are not merely legal basis, but also a reflection of the comprehension and the commitment from the government on inclusive development.

Bandung Regency as part of Metropolitan Bandung Area has a complex regional socioeconomic characteristic due to its representation of both rural and urban character. Compared to other districts and municipalities in West Java province, Developmental achievements in Bandung Regency 


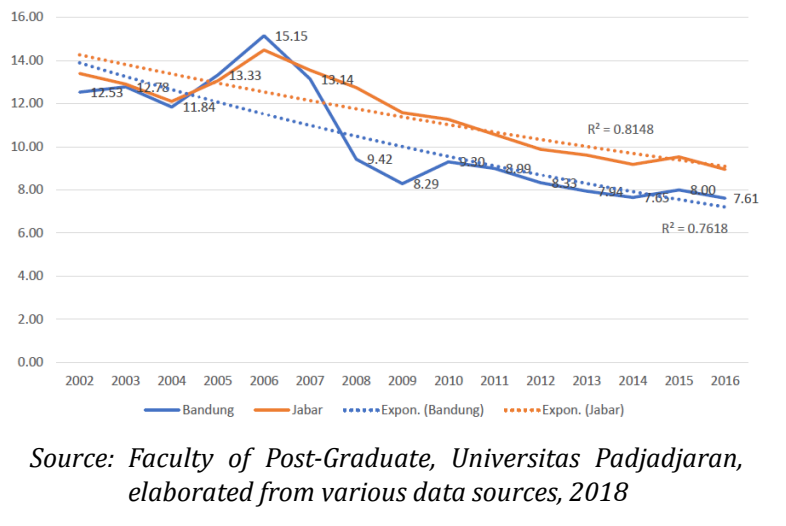

Figure 2. Poverty Rate in Bandung Regency 2002 - 2016

tend to be positive, for example the National Development Board BPS data (2011-2016) shows that since 2013, Bandung Regency's economic growth rate are always greater than the economic growth rate of West Java Province. The figure below also highlights Bandung Regency economic growth is more steady than national economic growth rate.

Other development indicator of Bandung regency also shows a good performance, as shown in the poverty rate that is lower than that of West Java province. It means that the success level of poverty reduction in Bandung Regency is faster compared to West Java Province.

Unfortunately, from 2014 the Gini Index ratio shows significant increases. This means that the income inequality is rising as seen in this picture:

Such condition provides a picture of the inadequacy of the development orientation that has so far been implemented in Bandung Regency. It is important to measure economic growth, but such measurements could never explain economic

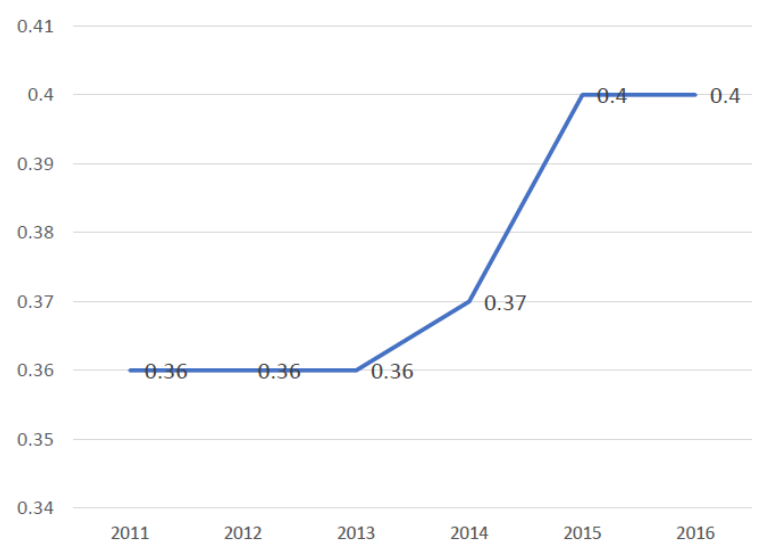

Source: Faculty of Post-Graduate, Universitas Padjadjaran, elaborated from various data sources, 2018

Figure 3. Gini Index of Bandung Regency (2011 - 2016) robustness of the middle and middle-low classes of a country. Development programs that focus on economic growth encourages poverty and global inequality since only $20 \%$ of the global population are able to enjoy over $70 \%$ of global income, or in another word, about $80 \%$ of world population are only capable of enjoying less than $30 \%$ of global income (Oxfam, 2018, p. 3). To address such inequality, inclusive development could be one alternative approach that could be used by the Bandung Regency Government in increasing its development achievement quality.

Slow growth, high unemployment and widening inequalities have placed inclusive development at the heart of the policy debate in many parts of the world. Central to this debate is the ability of governments to put in place policies that deliver stronger economic growth together with better sharing of the benefits of increased prosperity among social groups. These benefits go beyond income to include inclusive outcomes across the different dimensions that matter for societal well-being.

As one of the strategic actors in development, regionalgovernmentapparatus, especially thosewho are directly involved in development planning, hold a key role in translating inclusive development into development planning practices. This article aims to analyze the perception of regional government apparatus who are involved in the development planning on the concept of inclusive development. In the absence of inclusive development, the people at the grassroots, that is, the intended beneficiaries of poverty alleviation programs, are left abjectly dependent on a bureaucratic delivery mechanism over which they have no effective control. Government apparatus play strategic role to design and operate delivery mechanism to ensure that all the people, especially those who marginalized from development process and result, could obtain equal access and opportunity to increase their living hood. Therefore, understanding of the government apparatus' perception toward inclusive development indicates the political commitment to create inclusiveness in development (Hickey, 2015), and later enhance policy coherence to redistribute growth for all, including the marginalized groups.

\section{METHOD}

To discover the perception of regional government on inclusive development, quantitative method is used by employing questionnaires. Respondents are determined through a purposive method, which targets regional government apparatus who bear the main responsibilities and 
functions that are directly related to development planning. Every respondent represents all regional government organizations that exist in Bandung Regency, which comprises of 33 local government units (Satuan Kerja Perangkat Daerah, SKPD) and 31 sub districts.

Datathatwere obtained from the questionnaires were then processed with the SPSS 25 software. Data analysis are done through descriptive statistics to identify the mode or the highest frequency of every question item in the questionnaire. The output of such statistical process was then interpreted to discover the level of comprehension of inclusive development of the regional government apparatus that are directly involved in development planning.

The output of the processed perception data was then confirmed by development planning documents which are the product of policies that were born from the process of deliberation of various stakeholders, such as non-governmental organization, community organization, etc. Despite being compiled through participatory means, in this case through development planning participatory forum (forum musyawarah perencanaan pembangunan), from village level to national level. This forum is a mean for bottom-up planning process that provides various stakeholders to articulate their interests and aspirations into development programs. The planning documents were also designed through the technocratic process in which government apparatus, especially the development planners, play an important role in translating development paradigms into programs and activities.

To analyze how inclusive development are translated into development planning documents in Bandung Regency, this research uses content analysis of development planning documents in Bandung Regency. This analysis is a research technique to produce an inference that is replicable and valid according to context (Krippendorff, 1991). This analysis was done on the contents of Bandung Regency development planning documents that are comprised of Bandung Regency Long Term Development Planning 2005-2025 (Rencana Pembangunan Jangka Panjang Kabupaten Bandung, RPJPD 2005-2025), Bandung Regency Medium Term Development Planning 2016-2021(Rencana Pembangunan Jangka Menengah Kabupaten Bandung, RPJMD 2016-2021), and Bandung Regency Action Plan (Rencana Kerja Pembangunan Daerah, RKPD Kabupaten Bandung) year 2016, 2017, and 2018.

Krippendorff (1991, pp. 44-45) stated that several forms of classifications in content analysis, which are: pragmatic content analysis, in which classification is done on signs according to plausible cause and effect. For example, a word that is pronounced several times could result in the formation of an attitude of something. The second classification is the semantic content analysis, which is done to classify a sign according to its meaning. The third classification is sign-vehicle analysis which is done to analyze message content through psychophysical properties of a sign, such as counting how many times the word "inclusive" appears. The three classifications are used to identify how inclusivity is translated to the development planning document in Bandung Regency.

Data processing was done with Nvivo version 12 software to count the frequency of a word that is assumed to represent the concept of inclusive development. The nodes that are used are:

1. Marginalized groups, that are identified based on keywords gender, women, ethnicity, age (youth and elderly), as well as physical/ psychological condition (diffable)

2. Social dimension, that is identified based on keywords "increasing capacity, opportunities, and dignity"; "broadening respect and recognition, strengthening social bonds, cohesion, integration, and solidarity"; as well as "broadening participation".

3. Economic dimension, which is identified based on keywords "equity"; "income distribution"; and "welfare distribution".

4. Political dimension, which is identified based on keywords "participation of all stakeholders".

5. Environmental dimension, which is identified based on keywords "minimalizing environmental degradation".

The collected data then analyzed by interpretation to understand the meanings contained in them.

\section{RESULTS AND DISCUSSION}

In this section, analysis will be focused to show the political commitment of government apparatus in translating inclusive development into developing planning policy and practice. This commitment is elaborated through two dimensions conceptualized by Hickey (2015, pp. 3-4). The first, is to go beyond a narrow understanding of development as a primarily economic process to one with an integral focus on the achievement of equity and the rights of citizenship. This is important to prove that the forms of politics that have underpinned inclusive forms of development, differ in significant respects from those associated with economic growth. The second move is to shift the focus beyond 'poverty' 
and 'the poor'. A discourse on poverty can make it difficult to think politically and may distract from a focus on achieving the fuller goal of social justice implied by the term 'inclusive development'. More instrumentally, a focus on inclusion responds to evidence that there may be greater political support for interventions that include non-poor as well as poor groups (Nelson, 2003, p. 121), both in terms of better-off groups being more adept at attracting public goods provision and at maintaining a better quality of service delivery. The intention here then is to develop a more encompassing and relational view of development that problematizes the workings of societies rather than the characteristics of particular groups and involves thinking in broader terms around how to achieve social justice, towards which poverty reduction is an essential but insufficient step.

In terms of our specific focus on political commitment, this concept is defined as "the extent of committed support among key decision makers for a particular policy solution to a particular problem" (Post, Raile, \& Raile, 2010, p. 569). However, this policy-focused approach needs to be located in the broader context within which these key decisionmakers operate, particularly in terms of their relationships to other elites. Here we define political elites as those "who have the organized capacity to make real political trouble" (Burton \& Higley, 2001, p. 192), and include those holding valued assets (e.g. capitalists); those holding the power of adjudication over the distribution, allocation and regulation of property rights and use of property more broadly; those who possess authority to bargain on behalf of organized social groupings (Hickey, 2015, p. 5); and those who play a role in establishing dominant ideas (e.g. public intellectuals, media owners). Importantly, these definitions draw attention to the role of elites at local as well as national levels, with the local often providing the key space within which development is actually delivered and where the ordinary subjects of development are most likely to interact with elites (Chatterjee, 2004).

First, we elaborate the description of respondents in this research. The respondents are regional-level governmental apparatus that are directly involved in development planning in Bandung Regency. Every respondent is chosen as the representative of regional governmental organization in Bandung Regency, including those in the districts level. According to their gender, $66.07 \%$ are male, and $32.14 \%$ are female.

Most of the respondents are aged 50-54 and 45-49 years old. This indicates that respondents possess sufficient work experience in the regional government, that they have prior knowledge on

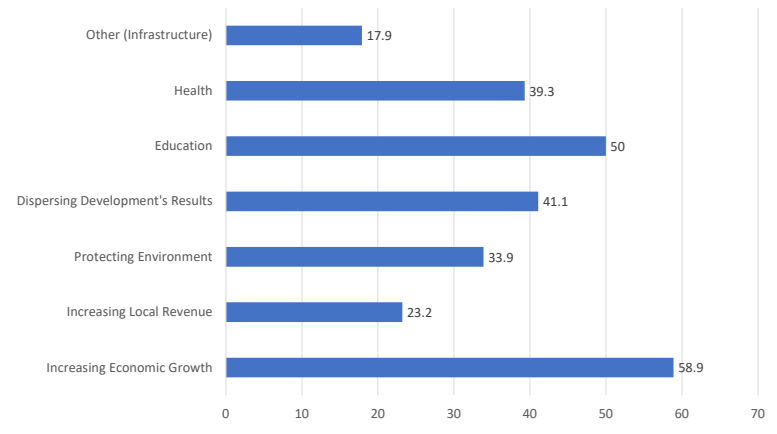

Source: Research Output, processed, 2018

Figure 4. Development Priorities in Bandung Regency

development planning practices in the region, especially in Bandung District. This fact is confirmed by the employee rank and class of the respondents who are mainly composed of Group III Public Officials.

The validity of the data is also confirmed by the rank or the position of the respondents in their respective regional government organization. In accordance with the research purposes, the respondents are chosen through a purposive method, which targets regional government apparatus who bear the main responsibility and functions that are directly related to development planning in every work unit.

Every respondent has generally held their position for 2 (two) years (30.36\%), so that their understanding and experiences are sufficient to answer the questions that are asked in the questionnaires. In accordance to their level of education and study program, the respondents have relevant educational backgrounds and a majority having a line of work in development planning, with the majority holding degrees in Public Administration (14.2\%) and Government Sciences / Public Policy (14.2\%)

Generally, respondents perceive development as a process that has more economic oriented dimension. This is shown from the respondents' answers when asked about what the priority of development in Bandung Regency is. The following figure shows that even though the respondents know that development encompass economic, education, and health dimensions as stipulated in the human development paradigm, a large proportion of respondents believe that the economic dimension of development is the most important aspect in the local development planning. The survey revealed that $58.9 \%$ respondents consider increasing economic growth is more important than increasing locally generated income (23.2\%). 


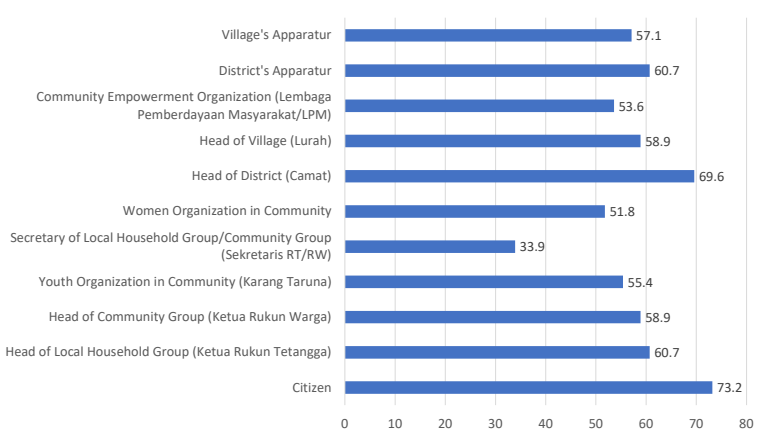

Source: Research Output, processed, 2018

Figure 5. Actors in Development Planning

However, in terms of equal development, $41.1 \%$ of respondents agree that development needs to prioritize the equal distribution of development outputs. This indicates that there is an awareness for the economic development to be matched by an equal distribution of development to overcome the inequality that arise from development.

These results indicate that majority of government apparatus still perceive development as primarily economic process, eventhough they begin to aknowledge the necessity of equity in distributing welfare to decrease economic gap. Rising income inequality has been associated with higher economic volatility and slower progress in human development (van Gent, 2017), nevertheless the growing awareness of inequality among bureaucrats could initiate the process of development to become more participative.

According to the respondents, access to participation in development planning is widely open to all levels of society. This is stated by respondents' answers on what actors are involved in development planning on a grass root level. Based on the following answers, citizens become an actor which participation is quite high in

Table 1.

Scope of Participation by Marginal Groups in Development Planning in Bandung Regency

\begin{tabular}{|c|c|c|c|}
\hline Marginal Groups & Scope of Participation & $\begin{array}{l}\text { Majority Response } \\
\text { (\%) }\end{array}$ & $\begin{array}{l}\text { Abstain } \\
\text { (\%) }\end{array}$ \\
\hline Women & $\begin{array}{l}\text { Local neighbourhood (Rukun Tetangga), Local community } \\
\text { (Rukun Warga), Village, Ditrict, Regency }\end{array}$ & 19.6 & 10.7 \\
\hline Elderly & $\begin{array}{l}\text { Local neighbourhood (Rukun Tetangga), Local community } \\
\text { (Rukun Warga), Village, Ditrict, Regency }\end{array}$ & 30.4 & 17.9 \\
\hline Youth & $\begin{array}{l}\text { Local neighbourhood (Rukun Tetangga), Local community } \\
\text { (Rukun Warga), Village, Ditrict, Regency }\end{array}$ & 51.8 & 8.9 \\
\hline Poor household & $\begin{array}{l}\text { Local neighbourhood (Rukun Tetangga), Local community } \\
\text { (Rukun Warga), Village, Ditrict, Regency }\end{array}$ & 25 & 30.4 \\
\hline Disability & $\begin{array}{l}\text { Local neighbourhood (Rukun Tetangga), Local community } \\
\text { (Rukun Warga), Village, Ditrict, Regency }\end{array}$ & 16.1 & 48.2 \\
\hline Non-Sundanesse Ethnics & $\begin{array}{l}\text { Local neighbourhood (Rukun Tetangga), Local community } \\
\text { (Rukun Warga), Village, Ditrict, Regency }\end{array}$ & 41.1 & 30.4 \\
\hline Non-Islam Religion & $\begin{array}{l}\text { Local neighbourhood (Rukun Tetangga), Local community } \\
\text { (Rukun Warga), Village, Ditrict, Regency }\end{array}$ & 42.9 & 26.8 \\
\hline Isolated community & $\begin{array}{l}\text { Local neighbourhood (Rukun Tetangga), Local community } \\
\text { (Rukun Warga), Village, Ditrict, Regency }\end{array}$ & 21.4 & 50 \\
\hline Low educated/illiterate community & $\begin{array}{l}\text { Local neighbourhood (Rukun Tetangga), Local community } \\
\text { (Rukun Warga), Village, Ditrict, Regency }\end{array}$ & 23.2 & 48.2 \\
\hline Farming/factory worker & $\begin{array}{l}\text { Local neighbourhood (Rukun Tetangga), Local community } \\
\text { (Rukun Warga), Village, Ditrict, Regency }\end{array}$ & 41.1 & 30.4 \\
\hline Unemployement & $\begin{array}{l}\text { Local neighbourhood (Rukun Tetangga), Local community } \\
\text { (Rukun Warga), Village, Ditrict, Regency }\end{array}$ & 28.6 & 35.7 \\
\hline
\end{tabular}

Source: Research Output, processed, 2018 


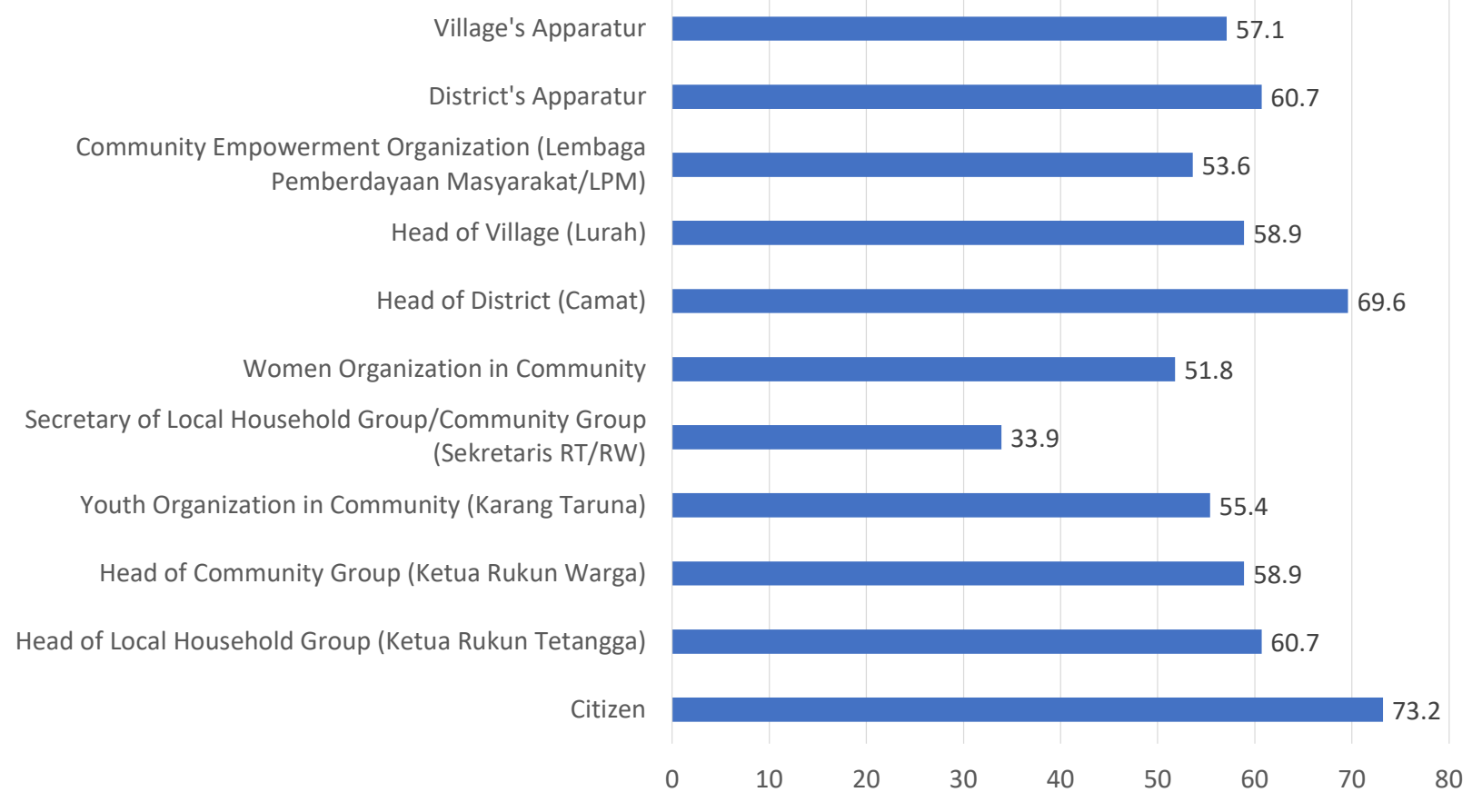

Source: Research Output, processed, 2018

Figure 6. Causes of Inactivity of Marginal Groups in Development

planning $(73.2 \%)$. This figure is fair, bearing in mind that government elites' participation, from the community level (Ketua RT/RW) to the district level is still rather high. This could not be separated from the fact that the government still possess a strong role in the process of planning and implementing development. Citizens' participation is mostly in the scope of development planning discussion (musrenbang) that is implemented on a leveled basis, starting from RT/RW to the regency level.

In such development planning process, the role of men is identified to be dominant by $75 \%$ of the respondents. Although, there are also respondents that answered that there is already equality between male and female in the development participation levels (10.7\% respondents).

The above data shows that a majority of the respondents stated that all eleven marginal groups are involved in all development planning levels through the musrenbang forum (from the RT/ RW level to the regency level). But, an interesting point to analyze is the varying percentage of respondents to every marginal groups. Only $19.6 \%$ of the respondents answered female are involved in all musrenbang forum. This figure only stands a few points higher than the participation of diffable whose participation are identified by $16.1 \%$ of the respondents. This answer is in line with the percentage of respondents that stated that male still hold a dominant role in the development planning process.

On another side, empty answers or "do not know" on several marginal groups also indicate that respondents do not know or could not identify the presence of the marginal groups in musrenbang. Among the marginal groups whose participation is relatively limited according to the table above are the citizens with low education/ illiterate and isolated citizens.

The reason to the lack of active participation from marginal groups, according to the respondents are due to the following challenges:

Passive attitude in development planning is not only represented from reasons above, but also from those with the role of decision-maker to decide on priority recommendations. Respondents answers mostly stated that heads of regional organizations are those who are most detrimental to the priorities in development recommendations. In the case of lack of participation from civil groups, including marginal groups, the strategic role of heads of these heads of regional organizations have to be equipped with sufficient development planning capabilities, on an individual as well as an organizational level.

Infrastructure is named as the priority field in development. The large geographical condition of Bandung Regency that covers numerous-widely spread districts and villages, seems to be the main 
reason why infrastructure is seen as a priority in development. Despite not directly related to inclusive development, infrastructure is also a dimension that could have a strategic role to broaden marginal groups' access to development outputs.

Gender issues become one of the important issues that have been accommodated in Bandung Regency planning documents. The results of data processing by Nvivo Plus version 12 software, with query text search function have found that the word "gender" appear the most in 2016 RKPD document as much as 17 times, and the least in RPJMD 20162021 as little as 2 times. The emergence of the word "gender" if mapped in more detail in relations to the context of the sentences or parts of the planning documents, shows that the government of Bandung Regency are committed to implement gender equality, especially through female and children empowerment programs.

The gender equality commitment is explicitly stated in relations to the phrases: "... eradicating disparity..."; "... in efforts to realize gender equality", “... encouraging gender equality..."; as well as “... gender mainstreaming...". Such statements show that gender issues that are connected with the recognition of marginal groups, especially women and children, are acknowledged as a development subject that is addressed through various development programs.

The use of the word "female" in the five planning documents that become the unit of analysis in this research are more in numbers than the word "gender". This fact shows a greater level of care that is more specific towards female in the context of development. The emergence of the word "female" is in-line with the statements of anti-discrimination towards female; capacity-building activities for female organizations; female empowerment and child protection; female workers; and female as a category of gender. The frequency of the use of the word "female" in all five development planning documents in Bandung Regency could not be separated from the gender mainstreaming campaign that has started for long, so that many programs in relation to the empowerment of female have been adopted in the planning document.

Aside from female, other groups that are regarded to be important in the concept of inclusive development are ethnic groups, especially minority ethnics, that are often not involved in development. Research towards development planning documents in Bandung Regency showed only 1 (one) planning document that stated the word "ethnic", that is the 2018 RKPD.
The use of the word "ethnic" in 2018 RKPD is a form of the adoption of a goal of the Sustainable Development Goals (SDGs) that are adopted as a development policy orientation by the Bandung Regency Government. Yet, in the following parts of the 2018 RKPD document, the word "ethnic" were not used, which led to ambiguity in how this policy is further elaborated in the development program.

Inclusive development also calls for the implementation of development to cater citizens from a wide range of age. The economic development paradigm tends to focus on citizens of productive age as the subjects of development, whilst those in non-productive age are classified as dependents of citizens of productive age. This kind of understanding classifies citizens of non-productive age as a "burden" and marginalized them in the process of development. On another side, such marginalization also results in the deprivation of such group from their interests, which led to not only them losing access to participate in development, but also losing access to the outputs of development.

In the context of this research, the recognition of marginal groups from the age aspect will be seen through the existence of the youth group and elderly group in development planning documents. Data processing results showed that the use of the word "youth" is relatively high in almost all planning documents. Despite that, their contextual scope is still small.

The word "youth" is seen in various contexts, but most point towards the issue of guidance, be that guidance through youth organizations or guidance through various interest and talent activities, such as sports, entrepreneurship trainings, and other skills-related trainings.

The existence of youth groups is also related to social problems such as the use of narcotics and drugs. These issues seem to correlate directly with how these youth groups are often seen as a threat to social security. This perception manifested itself in local development programs that focuses on narcotics and drugs education. These youth groups are often the objectified as a vulnerable group that has to be protected. Local development programs for youths also highlights the prevailing unemployment issues through skill improvement training. These youth groups also have great potential in advancing local economic growth. Especially in the context of the creative industry, digital economic platforms and start up industries.

On the other side, elderly groups (lansia) also gain a considerable portion of the development planning documents in Bandung Regency, especially in 2016 RKPD. The use of the word "lansia" implies that they are a vulnerable group that is assumed to 
be facing challenges in health and abandonment by their families. These two issues became the main foundation in the formulation of development programs aimed at the elderly.

Other groups that face the potential of marginalization in inclusive development are the diffable group, who are those who possess different physical and psychological capabilities with the population in general. The word "diffable" emerged in the context of public service, especially those related to the provision of basic infrastructure and social security for diffable individuals.

According to the data that was gathered using the text query analysis, the existence of marginal groups is acknowledged and accommodated by the development planning documents in Bandung Regency. These groups are positioned as vulnerable groups that are facing several challenges, among others, violence and equality (female group), discrimination (for ethnic groups), threats of narcotics (youth group), health and abandonment (elderly group), basic infrastructure and social security (diffable group).

Those challenges are a reflection of aspirations or the interests of marginal groups that are understood from the regional government standpoint, by referring to national and provincial planning documents. Despite so, the scope of the interests of those marginal groups are not significant if contextualized to the planning documents as a whole. This indicates that the existence of aspiration or interests from marginal groups are still normative and have not been interpreted thoroughly into development programs as well as more specific and tangible development measurements. There is a detachment between the government's commitment that serves as the foundation of development and the translation of such policy into a more practical as well as affirmative level.

Among the marginal groups, ethnic groups are the entities that are most underrepresented in the development planning documents. This leads to an interpretation that in the context of Bandung Regency, the existence of various ethnic groups is not recognized as a conflictual issue, resulting in no program that is aimed to manage relations between ethnics.

From the inclusive development dimension, our textual analysis on development planning documents found that the keywords on the social dimensions, such as "increasing capacity, opportunities, and dignity"; "broadening respect and recognition, strengthening social bonds, cohesion, integration, and solidarity"; as well as "broadening participation" could not be found in those exact terms, but a separate search on the keywords that make up those phrases could still be found in the planning documents. This shows that the objectives of inclusive development have not explicitly been included in the planning documents of Bandung Regency, especially those in relations to the efforts of minimalizing the dimensions that block marginal groups' access from the overall progress of development.

The emergence of several keywords that are the characteristics of inclusive development, such as opportunity, capacity, participation, social solidarity, environment, as well as participation are still general in nature. Those words are not specifically directed towards marginal groups, but towards all members of the society.

There are several keywords that has become the characteristics of inclusive development in the social dimension that is not included in the development planning documents, which are "respect", "recognition", "social bond", and "cohesion". Meanwhile, the word "social solidarity" appears in a context that is not related to inclusive development, but to the context of social relations. The same goes for the word "participation" that appears in several parts of the planning document, but is not in the context of inclusive development, instead in a general context as a form of citizen participation in development.

Textual analysis on inclusive development dimensions showed that the keywords that represent economic, social, political, and environmental dimensions are included in the planning document. Economic dimensions are identified based on these keywords, "equity"; "income distribution"; and "welfare distribution". The word "equity" describes the spread of development process as well as its outputs to all stakeholders. In data analysis using Nvivo, the word "equity" only makes up 0,02\% of the planning document contents. The word "equity" appears in relations to the development distribution. In this context, "equity" is not aimed to any marginal group in particular, but rather more as a strategy so that development is not centralized in a certain region.

The political dimension is identified based on the keywords "participation of all stakeholders". This keyword is spread across all five planning documents with a relatively high number. But it has a rather normative context as part of the development planning principles, that is the participation principle. The use of this phrase is not in the context of provision of participatory access for marginal groups in development planning.

The environmental dimension is identified based on the keywords "minimizing environmental degradation". Just as the political dimension, the 
keyword "minimizing environmental degradation" appears in the development planning document in the context of Sustainable Development Goals (SDGs), and not in the context of the interests of marginal groups that are suffered from environmental degradation. The environmental dimension intersects lightly with marginal groups if it were placed in the context of disaster management, in which marginal groups are often positioned as the beneficiary of disaster-related programs that are implemented by the government.

From the research, it could be seen that in general, document analysis on development planning in Bandung Regency have yet to show an integration between the inclusive development concept optimally. There is a tendency to speculate that inclusive development is the responsibility of a particular organization that is directly involved with the issues of gender, elderly, diffable, and Person with Social Welfare Problems Penyandang Masalah Kesejahteraan Sosial (PMKS). SKPD documents for example, have not shown a relation with inclusive development, but are instead focused to their own basic tasks and functions (tupoksi). In several cases, governmental unit action plan (Renstra SKPD) itself is not related with strategic regional development issues, which results in the lack of innovation and ability to address challenges of development by the planned programs.

\section{CONCLUSION}

Inclusive development is a cross-sectoral issue that should be understood by all regional government apparatus and integrated in the planning documents in each task forces. This could explain why the achievements in the constantly improving economic growth could not be coupled with equal income distribution and could not answer strategic development issues optimally.

This preliminary research shows that government apparatuses still perceive development as means to achieve growth, and inclusive development is defined as equality between male and female in the development participation levels. Development planning process has not yet implemented the optimal public participation principle, and has not involved marginal groups, so that policies and programs could not accommodate several strategic regional issues.

Based on those findings, we can conclude that inclusive development as a paradigm is not yet been adapted in both policy and practice of development in Bandung Regency. Policy and practice of development has not gone beyond a narrow understanding of development as a primarily economic process to one with an integral focus on the achievement of equity and the rights of citizenship. Both policy and practice of development are also has not yet shift the focus beyond 'poverty' and 'the poor'. The issues of poverty and the poor are mentioned in development planning strategic documents. However, the programs create to overcome these issues are still uncomprehensive and sectoral based, aimed only to pursue macro indicators of development.

The multidimensional nature of inclusive development calls for capacity to deal with complex problems and to ensure strong levels of policy coherence. This, in turn, requires new approaches to policy making that enable the analysis of complementarities across policy sectors and levels of governments and encourage joined-up delivery. In addition, the planning apparatus should also perform a comprehensive analysis on the concept of inclusive development from other regional development stakeholders, as well as how far inclusive development policies and programs are implemented and used to answer issues of social and economic inequalities in Bandung Regency.

\section{ACKNOWLEDGMENT}

This article is part of a research "Inclusive Development Planning Model in Bandung Regency", that Is funded through research scheme between Bandung Regency Planning and Research Board (Badan Perencanaan dan Penelitian Pembangunan Daerah Kabupaten Bandung) and Center for Decentralization and Participatory Development Research (Pusat Studi Desentralisasi dan Pembangunan Partisipatif Fakultas Ilmu Sosial dan Ilmu Politik) Universitas Padjadjaran. The writers extend their gratitude to the head of Bappelitbang of Bandung Regency, as well as other government apparatus in Bandung Regency that have supported this research. Our gratitude is also conveyed to Diny Waskitawati, Puti Rizkiyansyah, Moh. Fahri, Kus Aliya Reza, Sakti Herliansyah, Desviny, dan Syachriza who collected field research data.

\section{REFERENCES}

Booth, D. (2011). Aid effectiveness: bringing country ownership (and politics) back in (No. 336). Retrieved from https://www.odi.org/ publications/4928-aid-effectiveness-bringingcountry-ownership-and-politics-back

Burton, M., \& Higley, J. (2001). The Study of Political Elite Transformations. International Review of Sociology, 11(2), 181-199. https://doi. org/10.1080/713674040 
Chatterjee, P. (2004). The Politics of the Governed: Reflections on Popular Politics in Most of the World. New York: Columbia University Press.

Gupta, J., Pouw, N. R. M., \& Ros-Tonen, M. A. F. (2015). Towards an Elaborated Theory of Inclusive Development. The European Journal of Development Research, 27(4), 541-559. https://doi.org/10.1057/ejdr.2015.30

Gupta, J., \& Vegelin, C. (2016). Sustainable development goals and inclusive development. International Environmental Agreements: Politics, Law and Economics, 16(3), 433-448. https://doi.org/10.1007/s10784-016-9323-z

Hickey, S. (2015). Thinking About the Politics of Inclusive Development: Towards a Relational Approach. SSRN Electronic Journal, (1), 1-34. https://doi.org/10.2139/ssrn.2425235

Hossain, N., \& Moore, M. (2002). Arguing for the Poor: Elites and Poverty in Developing Countries (No. 148). Retrieved from https://www.ids.ac.uk/ publications/arguing-for-the-poor-elites-andpoverty-in-developing-countries /

Krippendorff, K. (1991). Content Analysis: An Introduction to Its Methodology. Sage Publications.

Leftwich,A. (1995). Bringingpoliticsbackin:Towards a model of the developmental state. Journal of Development Studies, 31(3), 400-427. https:// doi.org/10.1080/00220389508422370

Nelson, J. (2003). Grounds for Alliance?: OVERLAPPING INTERESTS OF POOR AND NOT
SO P00R. In P. Houtzager \& M. Moore (Eds.), Changing Paths: International Development and the New Politics of Inclusion (pp. 119138). Retrieved from http://www.jstor.org/ stable/10.3998/mpub.17792.9

OECD. (2016). The Governance of Inclusive Growth. https://doi.org/10.1787/9789264257993-en

Oxfam. (2018). Oxfam Annual Report 2017 - 2018.

Post, L. A., Raile, A. N. W., \& Raile, E. D. (2010). Defining political will. Politics and Policy, 38(4), 653-676. https://doi.org/10.1111/j.17471346.2010.00253.x

Rauniyar, G., \& Kanbur, R. (2010). Inclusive growth and inclusive development: a review and synthesis of Asian Development Bank literature. Journal of the Asia Pacific Economy, 15(4), 455-469. https://doi.org/10.1080/135 47860.2010 .517680

Shankar Aiyar, M. (2015). Inclusive Governance for Inclusive Development. In J. P. Faguet \& C. Pöschl (Eds.),IsDecentralization GoodForDevelopment? (pp. 80-108). https://doi.org/10.1093/ acprof:oso/9780198737506.003.0004

van Gent, S. (2017). Beyond buzzwords: What is "inclusive development"? Leiden.

$\mathrm{Vu}, \mathrm{T}$. (2007). State formation and the origins of developmental states in south korea and indonesia. Studies in Comparative International Development, 41(4), 27-56. https://doi. org/10.1007/BF02800470 
This page is left blank. 